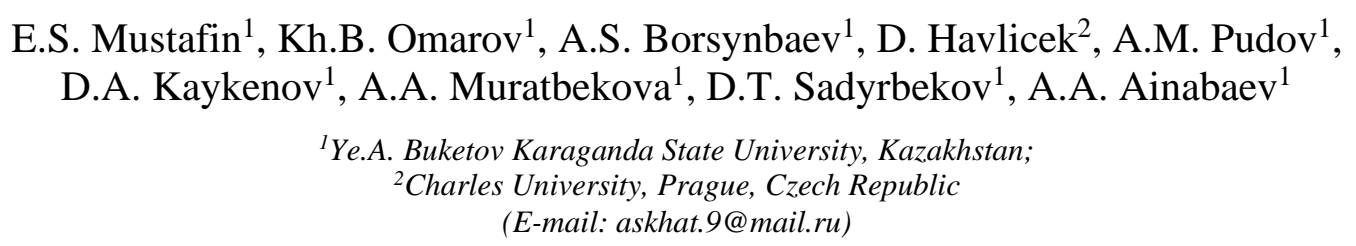

\title{
Possibility of enrichment of ore processing waste from Karagaily and Zheskazgan mining plants by dry separation method
}

\begin{abstract}
This study aims at review of the effects of dry separation method on the ore flotation efficiency and thoroughly discusses the possibility of waste enrichment by sieving through fine-mesh sieves with sizes $(\mathrm{d}>0.4$; $0.16<\mathrm{d}<0.4 ; 0.08<\mathrm{d}<0.16 ; \mathrm{d}<0.08 \mathrm{~mm}$ ). A granulometric analysis of four samples waste production, was carried out and the copper content in each fraction was determined. According to the results of the study, the following was established: 1) the largest proportion has a grain size fraction over the range $0.16-0.08 \mathrm{~mm}$ in the «current tails» of the Karagaily ore-processing plant, in this fraction turned out to be the highest copper content; 2) a larger amount of copper is contained in coarse fraction of «stored tails» and "current tails» of Zhezkazgan ore-processing plant 1-2, therefore, it is possible to sift out a finely dispersed fraction; 3 ) the largest fraction by grain size is over the range of $0.16-0.08 \mathrm{~mm}$ in «aged tails» of Zhezkazgan PP 3, but the largest weight percentage of copper is over the range $0.08<\mathrm{d}<0.16$. As a result of the studies, it was found that «current tails» and «stored tails» are applicable for the ore enrichment by dry separation method. The «Current tails» of the KPP are not suitable for enrichment by dry separation.
\end{abstract}

Keywords: concentration plant, tailings samples, analysis, fraction, grain sizes, screening, copper content, dry separation.

\section{Introduction}

The problem of handling solid waste is the most urgent component of ensuring national security for our country, since the volumes of accumulated waste are considered as one of the factors of the progressive environmental crisis. The sphere of secondary use of resources in Kazakhstan is at the stage of active formation. The purpose of this research was to study the possibility of using dry separation method for enrichment of ore processing waste from mining plants.

Today, special attention is paid to the problem of utilization of mining waste, as the use of technogenic mineral resources is not only one of the reserves of mineral raw materials for the mining industry, but also an important part of the state policy of resource saving and environmental protection.

Around the world, the process of mining and processing metal ores forms a large amount of waste of various aggregation state. At present, they contain billions of tons of ore that has undergone certain processing. Further accumulation of mining complex waste causes a serious problems of the environmental situation on the planet. The urgent issue is the creation of new environmentally friendly technologies for mining, focused on their maximum use [1].

Recent years, there is an increase in waste accumulation, therefore the environmental factor significantly impacts to the economy. According to the estimates of specialists from German metallurgical companies, the items of taxes and environmental costs of production have begun to gain the most weight recently. Therefore, progressive technologies for the production of metals from recycled materials are increasingly being introduced abroad. The sources of such raw materials are solid waste storage facilities of mining and metallurgical industries, the so-called technogenic deposits [2].

\section{Experimental}

The difficulty in separating of contaminants is caused mainly due to the moisture of the mass: with its increase, the stickiness of the impurities grows. In addition to moisture, the degree of stickiness is influenced by the grain and mineralogical compositions: the greatest stickiness is observed in clay and loamy soils, and less - in sandy loam, sand and stone dust formed during crushing. With the dry enrichment method, it is advisable to use cyclones for screening small fractions, since the use of vibrosieve with small mesh sizes is impossible due to the constant contamination of the holes [3, 4]. 
Therefore, for the enrichment of granules with a diameter of less than $1 \mathrm{~mm}$ by dry separation method, vibration systems are used. They are supplied with the platform and a separation plate with air blowing, which are inclined at certain angle to the horizontal. In this case it is possible to separate the mineral in accordance with their size under the influence of the vibration friction force.

The dry separation and enrichment unit includes a second vibration platform, which is installed on the second one-navigation separation. The angle of inclination and the direction of vibration force is approximately $20 \sim 60^{\circ}$. At least one gutter is installed on the indicated vibration platform, which is placed under the material inlet, a grating part is installed inside the gutter, the angle of the grating part and the vibration of the second platform is $2 \sim 20^{\circ}$. The sealed chamber is closed by the grating part, on the side wall of the gutter there is a gas inlet, at least one outlet for deposition and one more for the upper drain, a first, second, third, fourth partitions are installed around the side wall of the gutter. The above mentioned output for deposition is installed in the direction of low end of the sieve piece.

A useful effect is achieved by means of the vibration platform and a strainer, which are inclined to the vibration force. Enrichment and separation can be carried out in accordance with the mineral density. Moreover, due to the outlet for the upper discharge, the lighter material can be separated by the pouring method, which allows to achieve a good separation effect [5].

Four samples of the following grades have been taken for the experiment: 1) «current tails» of the Karagaily processing plant (KPP); 2) «stored tails» of the Zhezkazgan processing plant (ZHPP) No. 1, 2; 3) «current tails» of ZHPP; 4) «stored tails» of ZHPP No. 3 (grain sizes in samples are 0.01-0.5 mm). These samples have been subjected to study in terms of the possibility of enrichment with sieve methods.

Dispersion of the samples was determined by sieve analysis. It has been taken 250 grams of powder from the processing plants. This samples were passed through sieves with sizes $0.4,0.16$, and 0.08 . Before sifting large lumps of the sample were grinded in the mortar. Each fraction was weighed and the copper content was determined on the atomic absorption spectrometer «Varian AA-140».

\section{Results and Discussion}

The aim of our research work was to determine the feasibility of enriching these wastes by sieving through fine mesh sieves with sizes $(\mathrm{d}>0.4 ; 0.16<\mathrm{d}<0.4 ; 0.08<\mathrm{d}<0.16$; $\mathrm{d}<0.08 \mathrm{~mm})$. In order to achieve this purpose has been conducted a particle size analysis of mentioned above samples.

Assuming the dividing out of the number of grains by size to be the normal distribution, using the approximation and the Gauss function, it was determined the position of the distribution maximum and other statistical characteristics such as, the mathematical expectation and variance (Fig. 1).

For KPP «current tails», the distribution is described by a Gaussian curve with the following parameters: expectation is $0.11 \mathrm{~mm}$, variance $=0.05$, which confirms the normal distribution, i.e. uniform distribution in all fractions.

Based on the results of the mineralogical analysis, the granulometric analysis of the «Karagaily current tails» sample has been carried out. According to the results copper was in the form of chalcopyrite, due to its hardness that is contained in large fractions. Granulometric analysis of the remaining samples was also performed.

The results of this work are presented in the tables and depicted in the graphs below. As a result of conducted experiments the next data have been obtained. According to this values the sieves sizes, namely diameter impacts to the composition and copper content of considered samples. A maximum amount of mass fraction and copper content corresponds to the sieves with diameter between 0.08 and $0.16 \mathrm{~mm}$.

T a b l e 1

Results of particle size analysis of the sample «Current tails» (KPP)

\begin{tabular}{|c|c|c|c|}
\hline \multirow{2}{*}{ Sieve diameter, mm } & \multicolumn{2}{|c|}{ Mass fraction } & Average copper \\
\cline { 2 - 3 } & $\mathrm{g}$ & $\%$ & 0 \\
\hline $\mathrm{d}>0.4$ & 0 & 0 & 0.02 \\
\hline $0.16<\mathrm{d}<0.4$ & 71.18 & 28.47 & 0.18 \\
\hline $0.08<\mathrm{d}<0.16$ & 145.12 & 58.05 & 0.01 \\
\hline $\mathrm{d}<0.08$ & 33.7 & 13.48 & 0,11 \\
\hline For all fractions & 250.0 & 100 & \\
\hline
\end{tabular}


The average copper content for all fractions was calculated by the formula

$$
\mathrm{A}=\sum_{\mathrm{i}} \mathrm{p}_{\mathrm{i}} \mathrm{x}_{\mathrm{i}} A=\sum_{i} p_{i} x_{i}=0.0 \cdot 0+0.2847 \cdot 0.02+0.5805 \cdot 0.18+0.1348 \cdot 0.01=0.11
$$

As a result of the analysis (Table 1) it has been determined that the largest fraction of the grain size is in the range of $0.16-0.08 \mathrm{~mm}$, therefore, there is the highest copper content in this fraction.

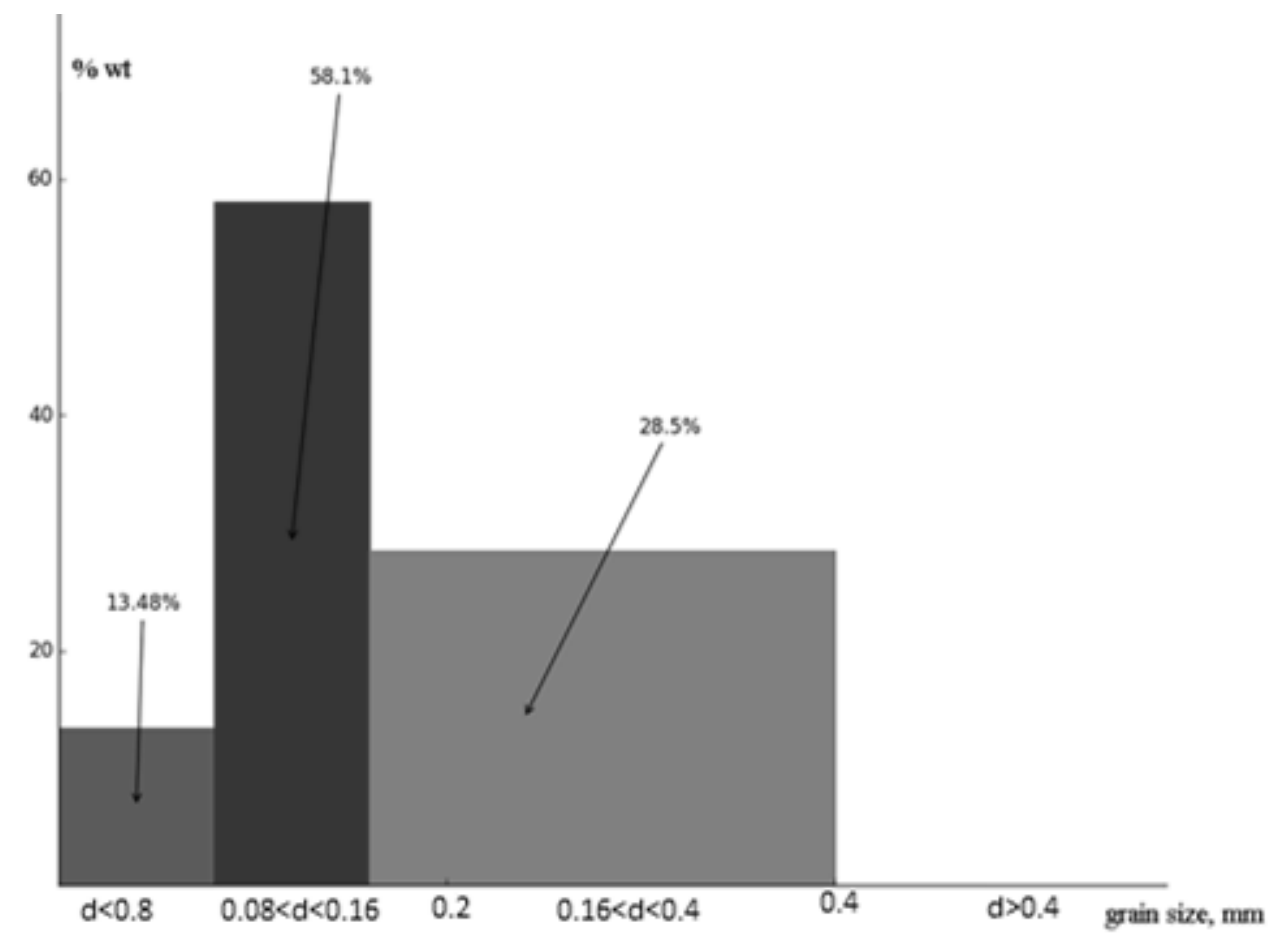

Figure 1. Distribution of the sample «current tails» of KPP by grain sizes

Based on the analysis, it was shown that division into fractions for enrichment is not feasible for the «current tailings» of KPP, since after sieving the percentage of waste will be much higher than in other samples. This fact makes the dry separation method ineffective for the mentioned above sample.

According to the results of the analysis of the «stored tailings» sample of ZHPP 1, 2 (Table 2) more copper is contained in the larger fractions of the sample therefore, it is possible to sift out the finely dispersed fraction and enrich the copper content of the tailings (Fig. 2).

Table 2

\section{Results of the granulometric analysis of the sample «Stored tails» of ZHPP 1,2}

\begin{tabular}{|c|c|c|c|}
\hline \multirow{2}{*}{ Sieve diameter, $\mathrm{mm}$} & \multicolumn{2}{|c|}{ Mass fraction, } & \multirow{2}{*}{$\begin{array}{c}\text { Average copper } \\
\text { content, } \%\end{array}$} \\
\cline { 2 - 3 } & $\mathrm{g}$ & $\%$ & 0 \\
\hline $\mathrm{d}>0.4$ & 0 & 0 & 0.11 \\
\hline $0.16<\mathrm{d}<0.4$ & 97.14 & 38.86 & 0.08 \\
\hline $0.08<\mathrm{d}<0.16$ & 124.54 & 49.82 & 0.01 \\
\hline $\mathrm{d}<0.08$ & 28.32 & 11.32 & 0.08 \\
\hline For all fractions & 250.0 & 100 & \\
\hline
\end{tabular}

According to the analysis results of the sample «current tailings» of ZHPP 1, 2 (Table 3) it is clear that, as well as the previous one, more copper is contained in the larger fractions of the sample, and in the diapason of $0.16<d<0.4$ the largest amount $(0.09 \%)$, therefore, it is possible to sift out the finely dispersed fraction and enrich the copper content (Fig. 3).

As a result of the analysis of the «stored tails» of ZHPP 3, it was determined that the largest fraction of the grain size is in the range of $0.4-0.16 \mathrm{~mm}$, but the largest percentage of the mass fraction of copper is in the fraction of $0.08<\mathrm{d}<0.16$. In this case, it is advisable to sift out the coarse fraction $\mathrm{d}>0.4$ (Fig. 4). 


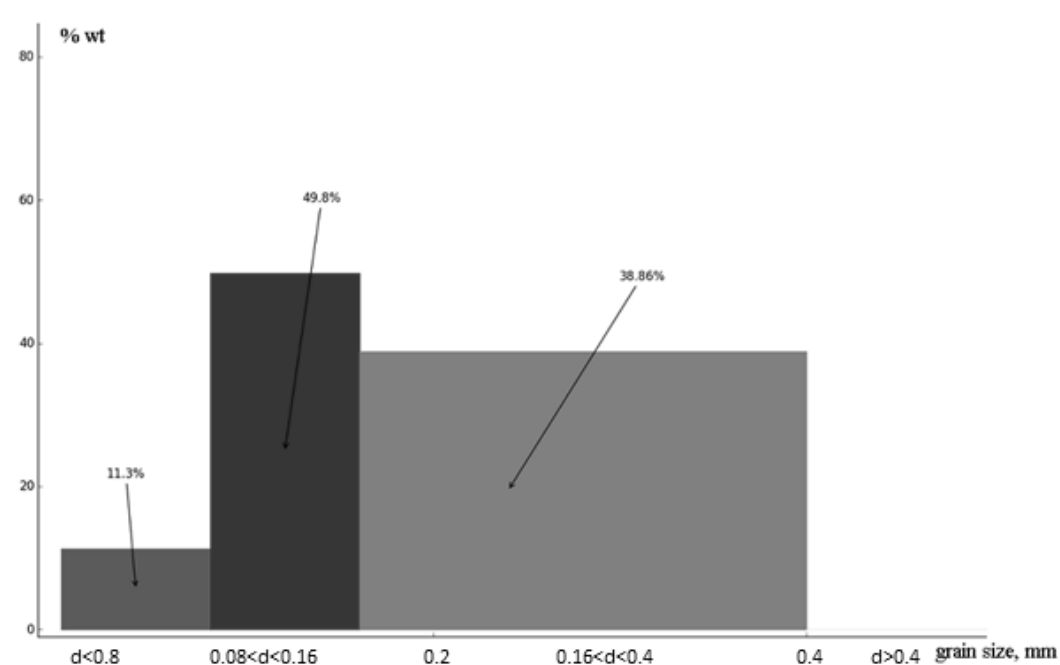

Figure 2. Distribution of the «stored tails» sample of ZHPP 1, 2 by grain size

Results of the granulometric analysis of the sample «Current tails» of ZHPP 1, 2

\begin{tabular}{|c|c|c|c|}
\hline \multirow{2}{*}{ Sieve diameter, $\mathrm{mm}$} & \multicolumn{2}{|c|}{ Mass fraction, } & \multirow{2}{*}{$\begin{array}{c}\text { Average copper } \\
\text { content, } \%\end{array}$} \\
\cline { 2 - 3 } & $\mathrm{g}$ & $\%$ & 0 \\
\hline $\mathrm{d}>0.4$ & 0 & 0 & 0.09 \\
\hline $0.16<\mathrm{d}<0.4$ & 128.01 & 51.20 & 0.08 \\
\hline $0.08<\mathrm{d}<0.16$ & 91.71 & 36.68 & 0.01 \\
\hline $\mathrm{d}<0.08$ & 30.28 & 12.12 & 0.07 \\
\hline For all fractions & 250.0 & 100 & \\
\hline
\end{tabular}

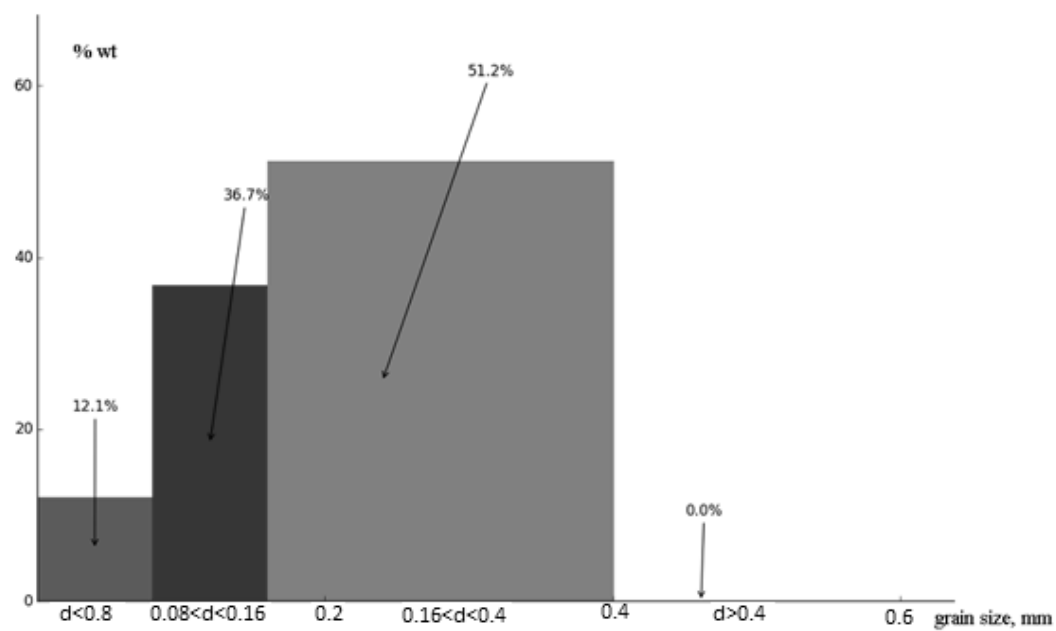

Figure 3. Distribution of current tailings sample by grain size 1, 2

Results of the particle size analysis of the sample «Stored tails» ZHPP 3

\begin{tabular}{|c|c|c|c|}
\hline \multirow{2}{*}{ Sieves diameter, mm } & \multicolumn{2}{|c|}{ Mass fraction, } & \multirow{2}{*}{$\begin{array}{c}\text { Average copper } \\
\text { content, } \%\end{array}$} \\
\cline { 2 - 3 } & $\mathrm{g}$ & $\%$ & 0.02 \\
\hline $\mathrm{d}>0.4$ & 11.88 & 4.75 & 0.06 \\
\hline $0.16<\mathrm{d}<0.4$ & 120.08 & 48.03 & 0.09 \\
\hline $0.08<\mathrm{d}<0.16$ & 59.67 & 23.87 & 0.01 \\
\hline $\mathrm{d}<0.08$ & 58.37 & 23.35 & 0.06 \\
\hline For all fractions & 250.0 & 100 & \\
\hline
\end{tabular}




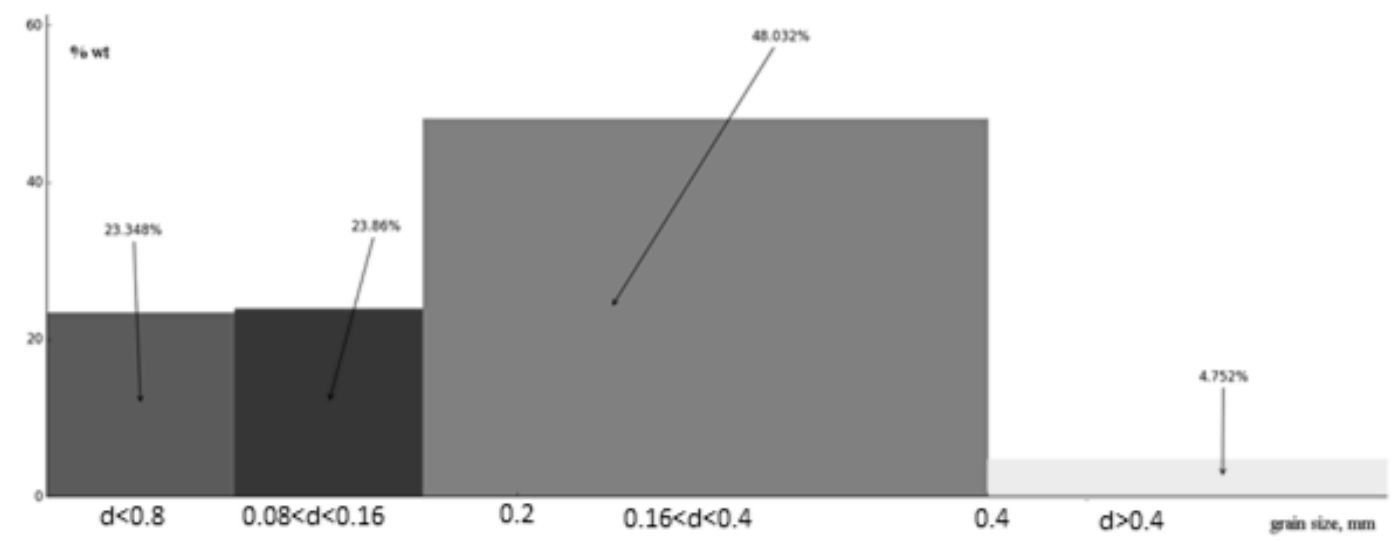

Figure 4. Distribution of the «stored tails» sample of the ZHPP 3 by grain size

The results obtained in this study indicate that the both «Current tails» and «Stored tails» of Zhezkazgan ore plant processing 1,2, and «Stored tails» of third sample KPP are suitable for the dry separation enrichment method. However the current tails of Karagaily plant have a Gaussian normal distribution of all fractions and the copper content is appropriate, so these samples are not suitable for enrichment by dry separation. The application of the dry separation method for this sample forms a large amount of waste, therefore, for this fraction, dry separation is ineffective.

The dry separation method allows to use the units with double vibrating platforms and sieve components located one above the other. The material for enrichment must be dried to a moisture content of $5 \%$.

The difficulty of separation of contaminants is mainly due to the humidity: the wetter is the sample, the stickier impurities are. The degree of stickiness, in addition to moisture, is influenced by grain and mineralogical compositions. The greatest stickiness is observed in clay and loamy soils, smaller one in sandy, sand and stone dust formed during crushing.

Therefore, to enrich granules with a diameter of less than $1 \mathrm{~mm}$ by the method of dry separation, vibration systems are used with the help of a platform and separation plate with a blow-by air, which are inclined at an angle to the horizon, then under the influence of vibration friction force it is possible to separate the mineral according to the size.

\section{Conclusions}

As a result of the research, it is established that the «current tails» of the ZHPP 1, 2 are suitable for enrichment by means of dry separation method; «stored tails» of the ZHPP 1, 2 and «stored tails» of the KPP 3 are applicable too.

Thus, dry separation plants with double vibration platforms and sieves located one above the other can be used to enrich the concentration plants tails by the dry separation method. The material for enrichment must be entirely dried to a humidity of $1.5-5.0 \%$.

The dry separation process is required to enrich maximum ore and obtain copper from sample materials, which is advantageous for the copper separation in subsequent processes.

The validation of the dry separation method allowed to demonstrate that the presence of copper in the ore tailings can be determined by means of simple methods of analysis. The pretreatment of the ore tailings is established under technical considerations, environmental pollution, capital costs and operational risks.

The advantages of dry separation method are the low capital and energy costs, in addition to the great flexibility to be environmental friendly. When used in the removal of soil contaminants, it reduces disposal costs and allows the recovery of precious metals.

\section{References}

1 Абрамов А.А. Технология переработки обогащения руд цветных металлов: учеб. пос. / А.А. Абрамов. — М.: Изд-во МГУ, 2005. - $330 \mathrm{c}$.

2 Алгебраистова Н.К. Технология обогащения руд цветных металлов: учеб. пос. / Н.К. Алгебраистова. — Красноярск: Изд-во СФУ, 2009. - 270 с. 
3 Чернегов Ю.А. Научно-технический прогресс и эффективность минерально-сырьевого комплекса / Ю.А. Чернегов // Горн. журн. - 2009. - № 1. - С. 43.

4 Руководство по обогащению отсева дробления разнопрочных каменных материалов. - [Электронный ресурс]. — Режим доступа: http://kitab.ttnda.az/upload-files/document/files/54/ 6.pdf

5 Патент 2577343 Россия. Способ сухой сепарации и обогащения и система для сухой сепарации и обогащения / ВАН Чжунву // Опубл. 03.20.2016.

Е.С. Мустафин, Х.Б. Омаров, А.С. Борсынбаев, Д.Хавличек, А.М. Пудов, Д.А. Кайкенов, А.А. Муратбекова, Д.Т. Садырбеков, А.А. Айнабаев

\title{
Қарағайлы және Жезқазған кен-байыту фабрикаларының қалдықтарын құрғақ бөлу әдісімен байыту мүмкіндігі
}

\begin{abstract}
Мақала құрғақ бөлу әдісінің кенді байыту тиімділігіне әсерін талдауға бағытталған. Сонымен қатар, өлшемдері ұсақ електерді (d > 0,4; 0,16 < d <0,4; 0,08< d <0,16, d < 0,08 мм) елеуіштер арқылы өткізіп, қалдықтарды байыту мүмкіндігі қарастырылған. Төрт қалдық үлгілерінің гранулометриялық сараптамасы жүргізіліп, олардың әрбір фракцияларындағы мыстың құрамдық мөлшері анықталған. Зерттеу нәтижелері бойынша: 1. Қарағайлы байыту фабрикасының «ағымдық қалдықтарының» 0,16-0,08 мм аралығындағы фракцияларында бөлшектердің өлшемі ең жоғары болатыны және осы фракцияларда мыстың ең жоғары мөлшері табылған; 2. Жезқазған байыту фабрикасының 1-2 үлгілерінің «ағымдық» және «жинақталған» қалдықтарында да мыстың мөлшері жоғары болады; 3. Бөлшектер мөлшерінің өлшемі бойынша ең үлкен фракция Жезқазған байыту комбинатының 3-үлгісіндегі 0,16-0,08 мм аралығындағы «жинақталған» қалдықтарда кездеседі. Зерттеулер нәтижесінде «ағымдық» және «жинақталған» қалдықтарды құрғақ бөлу әдісі арқылы байытуға болатыны анықталды. Қарағайлы байыту комбинатының «ағымдық» қалдықтары құрғақ бөлу әдісімен байытуға жарамайды.
\end{abstract}

Кілт сөздер: байыту фабрикасы, қалдық үлгілері, сараптама, фракция, түйіршік өлшемдері, елеу, мыстың құрамы, құрғақ бөлу.

Е.С. Мустафин, Х.Б. Омаров, А.С. Борсынбаев, Д.Хавличек, А.М. Пудов, Д.А. Кайкенов, А.А. Муратбекова, Д.Т. Садырбеков, А.А. Айнабаев

\section{Возможность обогащения отходов Карагайлинской и Жезказганской горно-обогатительных фабрик методом сухого разделения}

\begin{abstract}
Статья направлена на анализ влияния метода сухого разделения на эффективность обогащения руды. Кроме того, обсуждены возможности обогащения отходов путем просеивания через мелкие сита с размерами ( $\mathrm{d}>0,4 ; 0,16<\mathrm{d}<0,4 ; 0,08<\mathrm{d}<0,16, \mathrm{~d}<0,08$ мм). Был проведен гранулометрический анализ четырех образцов и определено содержание меди в каждой фракции. По результатам исследования было установлено: 1) наибольший размер зерна имеют фракции в диапазоне 0,16-0,08 мм в «текущих хвостах» Карагайлинского обогатительного комбината, в этой же фракции оказалось самое высокое содержание меди; 2) большое количество меди также обнаружено в крупной фракции «лежалых хвостов» и «текущих хвостов» Жезказганского обогатительного комбината $1-2$, поэтому здесь можно отфильтровать мелкодисперсную фракцию; 3) самая большая фракция по размеру зерна находится в диапазоне 0,16-0,08 мм в «лежалых хвостах» Жезказганского обогатительного комбината 3, но наибольший весовой процент меди находится в диапазоне $0,08<\mathrm{d}<0,16$. В результате исследований было установлено, что «текущие хвосты» и «лежалые хвосты» применимы для обогащения руды методом сухого разделения. «Текущие хвосты» Карагайлинского обогатительного комбината не подходят для обогащения путем сухого разделения.
\end{abstract}

Ключевые слова: обогатительная фабрика, образцы хвостов, анализ, фракция, размеры зерна, просеивание, содержание меди, сухая сепарация.

\section{References}

1 Abramov, A.A. (2005). Tekhnolohiia pererabotki obohashcheniia rud tsvetnykh metallov [Technology for processing and concentration of non-ferrous metal ores]. Moscow: MSU Publ. [in Russian].

2 Algebraistova, N.K. (2009). Tekhnolohiia obohashcheniia rud tsvetnykh metallov [Non-ferrous metal concentration technology]. Krasnoyarsk: SFU Publ. [in Russian]. 
3 Chernegov, Yu.A. (2009). Nauchno-tekhnicheskii prohress i effektivnost mineralno-syrevoho kompleksa [Technical progress and the effectiveness of the mineral resource complex]. Hornyi zhurnal-Mountain journal, 1, 43 [in Russian].

4 Rukovodstvo po obohashcheniiu otseva drobleniia raznoprochnykh kamennykh materialov [Guidelines for the enrichment of screening crushing different-strength stone materials] (n.d). kitab.ttnda.az. Retrieved from http://kitab.ttnda.az/upload-files/document/files/54/__ 6.pdf [in Russian].

5 Chzhunvu, V. (2016). Sposob sukhoi separatsii i obohashcheniia i sistema dlia sukhoi separatsii i obohashcheniia [The method of dry separation and enrichment and a system for dry separation and enrichment]. Patent 2577343. Russia. Publ. 03.20.2016 [in Russian]. 